\title{
Influence of magadiite dispersion states on the flammability of polystyrene and polyphenylene ether-polystyrene alloy nanocomposites
}

\author{
Hideaki Yukutake ${ }^{1}$, Motoyasu Kobayashi ${ }^{2}$, Hideyuki Otsuka ${ }^{2}$ and Atsushi Takahara ${ }^{2}$
}

A layered hydrous sodium silicate mineral, 'magadiite,' was uniformly exfoliated into polystyrene (PS) matrices to result in a PS/magadiite nanocomposite with high flame-retardant properties. Surface-initiated radical polymerization of styrene from the magadiite interlayer afforded PS graft chains along with exfoliation of each silicate layer to contribute to a uniform dispersion of inorganic nanosheet. The resulting PS-grafted magadiite (PS-g-magadiite) was then mixed with PS homopolymer by a meltblending process, forming PS/magadiite nanocomposites with fine dispersion of magadiite, which was confirmed by X-ray diffraction, transmission electron microscopy and dynamic mechanical analysis. A series of PS/magadiite composites with various dispersion states and blending ratios were molded into pressed-film-type test pieces to evaluate their flammabilities by cone calorimetric measurements. A peak heat release rate (PHRR) of well-dispersed PS/magadiite nanocomposites was half of that of the PS homopolymer. The dispersibility of magadiite was found to be a crucial factor for improving flammabilities for PS/magadiite composites. Polyphenylene ether-PS/magadiite nanocomposites were also prepared in a similar manner using the PS-g-magadiite nanosheet, but they could not suppress higher PHRR.

Polymer Journal (2010) 42, 223-231; doi:10.1038/pj.2009.336; published online 13 January 2010

Keywords: flammability; magadiite; melt blending; nanocomposites; polyphenylene ether; polystyrene; surface-initiated polymerization

\section{INTRODUCTION}

Some nanofillers, including clays, ${ }^{1,2}$ nanoparticles, ${ }^{3,4}$ carbon nanotubes $^{5-7}$ and polyhedral silsesquioxane, ${ }^{8,9}$ are currently being studied as flame retardants. Clays are environmentally benign and are quite practical materials with respect to cost. In particular, montmorillonite is a desirable layered inorganic compound that provides various polymeric materials with incombustible characteristics. ${ }^{10-17}$ In contrast, although magadiite is also a layered inorganic compound, no remarkable improvement in the flammability properties of polystyrene (PS)/magadiite composites has been reported thus far. ${ }^{18}$ We presume that poor dispersibility of magadiite in PS matrix must be the most significant factor for the low incombustibility of PS/magadiite composites. In the case of nanotubes, for example, it is well known that flame retardancy improves with better dispersion, higher loading and a higher interface area (aspect ratio) of the nanotubes. ${ }^{7,19}$ This tendency can be applied to polymer/clay systems; in other words, clays with better dispersion and higher aspect ratios should exhibit greater flame retardance. Therefore, magadiite with a relatively high aspect ratio ${ }^{20,21}$ must be a great potent candidate for high flame-retardant material only if magadiite can be successfully delaminated into polymer matrices.

In general, it is difficult to disperse magadiite platelets at nanoscales into nonpolar polymeric materials such as PS because magadiite has a multilayer structure in which the individual layers are tightly stacked together by electrostatic interactions. We recently immobilized an initiator for nitroxide-mediated polymerization onto the magadiite interlayer surface through the formation of covalent bonds to successfully delaminate magadiite platelets into the PS matrix by surfaceinitiated radical polymerization of styrene. ${ }^{22}$ Unfortunately, it was found that the resultant PS/magadiite nanocomposites exhibited a significant loss of fluidity. It is therefore important to improve the flow properties of PS/magadiite nanocomposites for processing.

In this study, we attempted to mix them with PS homopolymer through a melt-blending process in order to solve this problem. This combination of surface-initiated polymerization and melt blending is the first attempt to achieve both the processable flow properties of the nanocomposites and adequate dispersion for magadiite. The relationship between the dispersion states of magadiite and the flameretardant properties of PS/magadiite composites was evaluated by transmission electron microscopy (TEM), X-ray diffraction (XRD), dynamic mechanical analysis (DMA) and cone calorimetric measurements. We further focused our attention on a polyphenylene ether-polystyrene (PPE-PS) alloy that is made from PPE and PS homopolymers. It is usually rare for PPE to be used alone, it is mainly used as an alloy with PS. It is true that PPE has an advantage of being

${ }^{1}$ ADEKA Corporation, Minami-ku, Saitama, Japan and ${ }^{2}$ Institute for Materials Chemistry and Engineering, Kyushu University, Nishi-ku, Fukuoka, Japan Correspondence: H Yukutake, ADEKA Corporation, 5-2-13 Shirahata, Minami-ku, Saitama 336-0022, Japan.

E-mail: yukutake@adeka.co.jp

Received 3 September 2009; revised 1 December 2009; accepted 1 December 2009; published online 13 January 2010 
able to be miscible with $\mathrm{PS},{ }^{23,24}$ which provides well-balanced mechanical properties to the resultant material, but the resultant material loses the flame-retardant properties that PPE generally has. The lost flame-retardant properties should be covered by the exfoliation of magadiite into PPE-PS matrices. Therefore, the correlation between the dispersion states of magadiite and the flame-retardant properties of PPE-PS/magadiite composites was investigated as well.

\section{EXPERIMENTAL PROCEDURE}

\section{Materials}

Styrene was purchased from Kanto Chemical Co. Inc. (Tokyo, Japan) and purified by distillation under reduced pressure over calcium hydride. Figure 1 shows the chemical structure of 1-(3'-oxa-1'-phenyl-9'-trichlorosilylononyloxy)-4-methoxy-2,2,6,6-tetramethylpiperadine (OMTP), which was synthesized by a previously reported method. ${ }^{22} n$-Dodecyltrimethylammonium chloride (DTMA) and n-octyltrichlorosilane (OTS) were bought from Tokyo Chemical Industry Co. Ltd. (Tokyo, Japan) Wakogel C-200 (particle size 75$150 \mu \mathrm{m}$ ), which was used as a starting material for magadiite, was provided by Wako Pure Chemical Industries Ltd (Osaka, Japan), Na-magadiite was prepared by hydrothermal synthesis according to the method described in literature. ${ }^{25,26}$ Magadiite modified with DTMA (DTMA-magadiite) was prepared according to the published methods. ${ }^{20}$ PS $\left(M_{\mathrm{w}}: 200000\right)$ and PPE $\left(M_{\mathrm{w}}\right.$ : $50000)$ were obtained from Scientific Polymer Products Inc. (Ontario, NY, USA) An Omnipore membrane filter $(0.1 \mu \mathrm{m})$ was obtained from Millipore Corporation (Tokyo, Japan). Polytetrafluoroethylene (PTFE) tapes $(0.1 \mathrm{~mm}$ thick) were bought from Nichias Corporation (Tokyo, Japan). Boron nitride spray was purchased from Fine Chemical Japan Co. Ltd. (Tokyo, Japan) Other commercial reagents were obtained from Sigma-Aldrich Japan K.K., (Tokyo, Japan) Tokyo Chemical Industry Co. Ltd, Kanto Chemical Co. Inc. and Kokusan Chemical Co. Ltd (Tokyo, Japan), and were used without further purification.

\section{Preparation of magadiite anchored with the mixture of OTS and OMTP, and polymer/magadiite nanocomposites}

Immobilization of the mixture of OTS and OMTP onto the magadiite interlayer surface (OMTP-OTS-magadiite). Two different organosilanes were immobilized onto the magadiite interlayer surface by a previously reported method. ${ }^{22}$ DTMA-magadiite $(28 \mathrm{~g})$ was introduced into a $500 \mathrm{ml}$ four-necked flask and dried at $373 \mathrm{~K}$ under reduced pressure for $3 \mathrm{~h}$, then cooled to room temperature under ambient pressure. OTS $(280 \mathrm{mmol})$ and OMTP $(28 \mathrm{mmol})$ dissolved in $400 \mathrm{ml}$ of chloroform were added to the dried DTMA-magadiite, and the mixture was stirred at room temperature under $\mathrm{N}_{2}$ for $100 \mathrm{~h}$. The solid mass was dispersed in each solution, including $n$-hexane, acetone and distilled water, by ultrasonication for $3 \mathrm{~min}$ and centrifuged twice. Chlorine present in the solid mass was eliminated using a sodium hydrogen carbonate solution. After the solid mass was neutralized with a dilute solution of acetic acid, it was washed with distilled water and acetone and then collected with a $0.1 \mu \mathrm{m}$ membrane filter. The solid mass was dried in vacuo at room temperature for $12 \mathrm{~h}$ to result in $28 \mathrm{~g}$ of OMTP-OTS-magadiite.

Preparation of PS-grafted magadiite. A mixture of OMTP-OTS-magadiite $(6.0 \mathrm{~g})$ and styrene $(67.8 \mathrm{~g})$ was prepared in a glass tube and degassed by 10

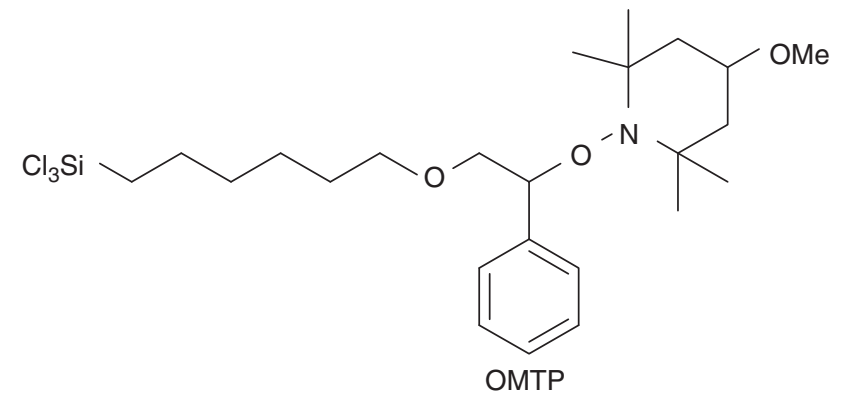

Figure 1 Chemical structure of OMTP. freeze-pump-thaw cycles under Ar atmosphere. Polymerization was carried out at $398 \mathrm{~K}$ for $40 \mathrm{~min}$ in the closed system, and was quenched by cooling and by the addition of a small amount of acetone. The solid material was dispersed in acetone solution by ultrasonication and then collected repeatedly by centrifugation until unbound PS was removed from the magadiite surface. The purified solid material was dried in vacuo at room temperature for $24 \mathrm{~h}$ to yield $23.8 \mathrm{~g}$ of PS-grafted magadiite (PS- $g$-magadiite) nanocomposites containing $25 \mathrm{wt} \%$ of magadiite. The magadiite content in PS matrices was determined by thermogravimetric analysis (TGA).

Melt-blending method of PS-g-magadiite and polymers. Polystyrene $(4.95 \mathrm{~g})$ and $0.05 \mathrm{~g}$ of PS- $g$-magadiite containing $10 \mathrm{wt} \%$ of magadiite were charged into the Labo Plastomill $\mu$ equipped with a KF-6 mixer (Toyoseiki seisaku-sho Ltd, Tokyo, Japan), and mixed by means of melt blending. Machine settings of $423 \mathrm{~K}, 100$ r.p.m. and $5 \mathrm{~min}$ were used for cylinder temperature, screw rotation and kneading time, respectively. A mixture was ejected in melt state, and then cooled down to room temperature. The solid mass was cut into small pieces using scissors to yield $5 \mathrm{~g}$ of PS/PS- $\mathrm{g}$-magadiite nanocomposites containing $0.1 \mathrm{wt} \%$ of magadiite with delaminated structures. Exfoliated PS/PS- $g$ magadiite nanocomposites containing $10 \mathrm{wt} \%$ of magadiite were obtained by melt blending with $3 \mathrm{~g}$ of PS and $2 \mathrm{~g}$ of PS- $g$-magadiite containing $25 \mathrm{wt} \%$ of magadiite under the same machine settings. Delaminated PPE/PS- $g$-magadiite nanocomposites containing $10 \mathrm{wt} \%$ of magadiite were prepared by melt blending with $2.93 \mathrm{~g}$ of PPE and $2.08 \mathrm{~g}$ of PS-g-magadiite containing $25 \mathrm{wt} \%$ of magadiite. Machine settings of $573 \mathrm{~K}, 100$ r.p.m. and $5 \mathrm{~min}$ were used for cylinder temperature, screw rotation and kneading time, respectively.

Melt-blending procedure of Na-magadiite and polymers. Polystyrene $(4.5 \mathrm{~g})$ and $0.5 \mathrm{~g}$ of Na-magadiite were introduced into the Labo Plastomill $\mu$ equipped with a KF-6 mixer, and mixed by melt blending to yield $5 \mathrm{~g}$ of PS/Na-magadiite composites containing $10 \mathrm{wt} \%$ of magadiite with agglomerated structures. Machine settings of $423 \mathrm{~K}, 100$ r.p.m. and $5 \mathrm{~min}$ were used for cylinder temperature, screw rotation and kneading time, respectively. Aggregated PPE-PS/Na-magadiite composites containing $10 \mathrm{wt} \%$ of magadiite were prepared by melt blending with $2.93 \mathrm{~g}$ of PPE, $1.58 \mathrm{~g}$ of PS and $0.5 \mathrm{~g}$ of Na-magadiite. Machine settings of $573 \mathrm{~K}, 100$ r.p.m. and $5 \mathrm{~min}$ were used for cylinder temperature, screw rotation and kneading time, respectively. Aggregated PS/DTMA-magadiite and PPE-PS/DTMA-magadiite composites were also prepared by the melt-blending method.

Preparation of press films of polymer/magadiite composites. The obtained PS composites were sandwiched by PTFE tapes at $503 \mathrm{~K}$ under $10 \mathrm{MPa}$ forming $100 \times 100 \times 3 \mathrm{~mm}^{3}$ sheets for the burning test. Sheets $\left(5 \times 40 \times 1 \mathrm{Mm}^{3}\right)$ for DMA were also prepared by a similar procedure. The resultant PPE-PS composites were sandwiched by PTFE tapes or aluminum boards sprayed with boron nitride spray at $573 \mathrm{~K}$ under $10 \mathrm{Mpa}$, forming $100 \times 100 \times 3$ and $5 \times 40 \times 1 \mathrm{~mm}^{3}$ sheets.

\section{Characterizations}

Polystyrene chains immobilized on magadiite were treated with a mixture of toluene and $3 \%$ hydrofluoric acid solution at room temperature for $24 \mathrm{~h}$. Calcium hydroxide was added to the mixture. Bound PS chains were extracted with toluene. The number-average molecular weight $\left(M_{\mathrm{n}}\right)$ and polydispersity index (PDI) of the bound PS chains were determined by size exclusion chromatography on a JASCO instrument equipped with a JASCO (Tokyo, Japan) 830-RI reflective index detection apparatus using tetrahydrofuran as an eluent, which ran through PS/divinyl PS/divinyl benzene gel (PLgel $5 \mu \mathrm{m}$ MIXED-C column $\times 3$, flow rate $0.8 \mathrm{ml} \mathrm{min}^{-1}$ ) at $313 \mathrm{~K}$. XRD was performed on an Ultima IV diffractometer (Rigaku Corporation, Tokyo, Japan) using $\lambda=0.15418 \mathrm{~nm}$ at $40 \mathrm{kV}$ of voltage and $40 \mathrm{~mA}$ current. The samples were ultramicrotomed with a diamond knife on an EM UC6 Ultramicrotome (Leica Microsystems, Tokyo, Japan) at room temperature to create sections $50 \mathrm{~nm}$ thick. The sections were transferred from the knife-edge to an elastic carbon support membrane, STEM100Cu grid (Okenshoji Co. Ltd, Tokyo, Japan). TEM images of a series of composites were observed with H-7500 (Hitachi HighTechnologies Corporation, Tokyo, Japan) at $100 \mathrm{kV}$ of acceleration voltage and $10 \mu \mathrm{A}$ of beam current. Optical microscopy images of a series of composites 
were observed with an Olympus BX-51 (Olympus Corporation, Tokyo, Japan) with a hot stage, an LK-600PM (Linkam Scientific Instruments Ltd, Tadworth, UK), in a nitrogen stream of $50 \mathrm{ml} \mathrm{min}^{-1}$ at $503 \mathrm{~K}$. TGA was carried out on a Thermoplus2 TG8120 (Rigaku Corporation) in a nitrogen stream of $200 \mathrm{mlmin}^{-1}$ at a scan rate of $10 \mathrm{~K} \mathrm{~min}^{-1}$, ranging from 303 to $1173 \mathrm{~K}$. A series of composites was prepared by means of melt blending with a Labo Plastomill $\mu$ equipped with a KF- 6 mixer. The films and sheets of a series of polymer composites were molded with a compression molding machine, a TBD-50-2 (Toho Machinery Co. Ltd, Tokyo, Japan), at a pressure of $10 \mathrm{MPa}$. The melt mass-flow rate (MFR) of PS composites was determined using a Melt Indexer (Toyoseiki seisaku-sho Ltd) at a heating temperature of $473 \mathrm{~K}$ and a load of $5.00 \mathrm{~kg}$. The relative order of the dispersion state of magadiite in polymer matrices was determined using a Rheovibron DDV-IIFP (A\&D Co. Ltd, Tokyo, Japan) from 123 to $573 \mathrm{~K}$ at a heating rate of $1 \mathrm{~K} \mathrm{~min}^{-1}$ and a frequency of $11 \mathrm{~Hz}$ under a $\mathrm{N}_{2}$ atmosphere. The flammability properties of a series of composites were evaluated using Cone III (Toyoseiki seisaku-sho Ltd). The heat release rate (HRR), ignition time and amount of residue were determined at an incident heat flux of $50 \mathrm{kWm}^{-2}$.

\section{RESULTS AND DISCUSSION}

Preparation of PS- $g$-magadiite

In a previous study, OMTP was immobilized onto the magadiite interlayer surface to perform surface-initiated polymerization of styrene. ${ }^{22}$ In this study, OMTP was diluted with OTS by less than $10 \mathrm{~mol} \%$ to be immobilized onto the magadiite interlayer surface. We exfoliated magadiite into the PS matrix by surface-initiated polymerization of styrene from the small amounts of OMTP present on the magadiite interlayer surface.

Figure 2 shows XRD patterns of DTMA-magadiite, OMTP-OTSmagadiite and PS- $g$-magadiite prepared by surface-initiated polymerization of styrene from OMTP-OTS-magadiite. DTMA-magadiite and OMTP-OTS-magadiite exhibited specific basal spacings depending on the size and conformation of organic molecules present in the interlayer. A diffraction peak derived from the basal spacing of magadiite was not observed for PS-g-magadiite. The results suggested that PS-g-magadiite could have delaminated structures caused by disarranging the regularity of basal spacings, because of PS chains grown from the interlayer surface.

A TEM image of PS- $g$-magadiite is illustrated in Figure 3, with the dark and light parts of the figure corresponding to magadiite layers and PS, respectively. This indicates that the individual magadiite layers were dispersed with grown PS chains. The relative narrow intervals between individual exfoliated magadiite layers were estimated to be around $10-20 \mathrm{~nm}$ because of the relatively high concentrations of magadiite $(25 \mathrm{wt} \%)$ in the PS matrix. The delamination of magadiite layers could have been caused by surface-initiated polymerization, even though the OMTP present on the magadiite interlayer surface was less than $10 \mathrm{~mol} \%$.

Table 1 summarizes the results of surface-initiated polymerization of styrene from OMTP-OTS-magadiite. As the surface-initiated polymerization was conducted for a relatively short period of time $(20 \mathrm{~min})$, the resulting PS- $g$-magadiite had a magadiite content of $50 \mathrm{wt} \%$. The surface-tethered PS chains had a high $M_{\mathrm{n}}$ of 125000 and a PDI of 1.96. Polymerization for $40 \mathrm{~min}$ resulted in a PS- $g$-magadiite with a magadiite content of $25 \mathrm{wt} \%$. The grafted PS chains had a higher $M_{\mathrm{n}}$ of 364000 and a PDI of 1.43. These results showed that exfoliated PS- $g$-magadiite with both a high $M_{\mathrm{n}}$ and a relatively narrow PDI can be obtained with a relatively short polymerization time by surface-initiated polymerization from OMTP-OTS-magadiite. However, in the case of PS- $g$-magadiite prepared by the method described in this study, one end of all PS chains was strongly bound with the magadiite interlayer surface. The bonds significantly restricted the

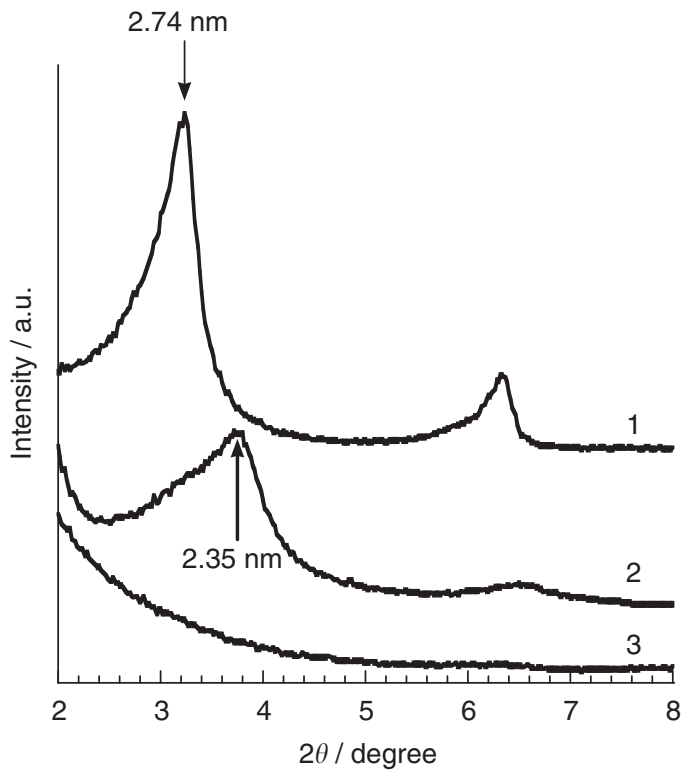

Figure 2 XRD patterns of a series of modified magadiite and PS- $g$ magadiite. (1) DTMA-magadiite, (2) OMTP-OTS-magadiite and (3) PS-gmagadiite prepared by surface-initiated polymerization from OMTP-OTSmagadiite for $40 \mathrm{~min}$, containing approximately $25 \mathrm{wt} \%$ of magadiite.

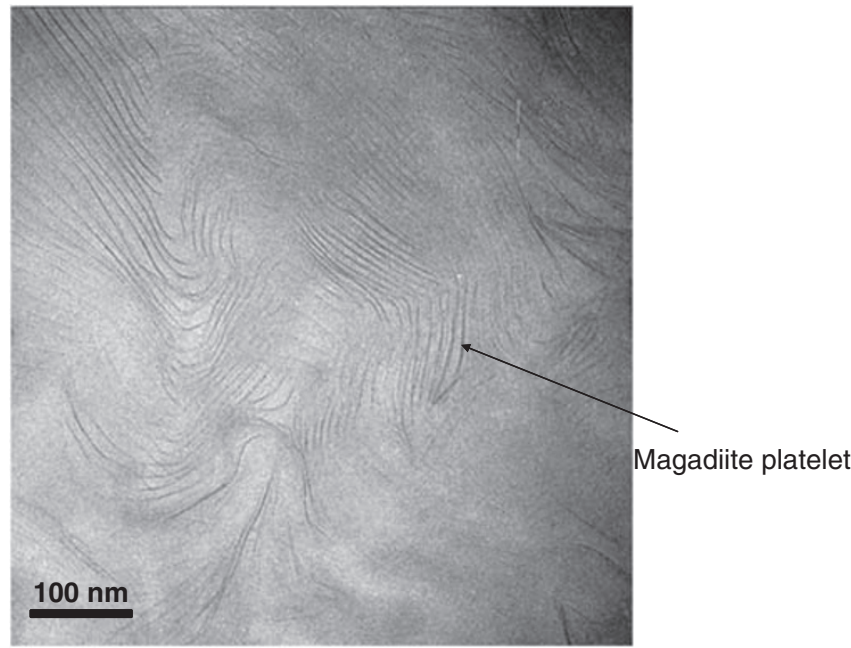

Figure 3 TEM image of PS-g-magadiite prepared by surface-initiated polymerization of styrene from OMTP-OTS-magadiite for $40 \mathrm{~min}$, containing approximately $25 \mathrm{wt} \%$ of magadiite. An ultrathin film measures $50 \mathrm{~nm}$ of thickness and was observed at blight field and a magnification of 200000. The inserted scale bar is $100 \mathrm{~nm}$.

molecular motion of PS chains, leading to a large loss of flow properties in PS- $g$-magadiite. The deterioration in fluidity created a serious disadvantage with regard to processibility in making the test pieces of nanocomposites.

\section{Improvement in flow properties}

Polystyrene/PS- $g$-magadiite nanocomposites were prepared by melt blending PS with PS- $g$-magadiite to improve the poor processibility of PS- $g$-magadiite. The melt-blending conditions are summarized in Table 2. The parameters of the melt-blending conditions include 
Table 1 Preparation of polystyrene-grafted-magadiite by surface-initiated polymerization of styrene at $398 \mathrm{~K}$

\begin{tabular}{lcccccc}
\hline & $\begin{array}{c}\text { OMTP-OTS-magadiite } \\
\text { Entry } \\
\text { /Styrene }\left(g^{-1}\right)\end{array}$ & $\begin{array}{c}\text { Polymn. } \\
\text { time (min) }\end{array}$ & $\begin{array}{c}\text { Yield } \\
(g)\end{array}$ & $\begin{array}{c}\text { Magadiite } \\
\text { content }(w+\%)\end{array}$ & $\begin{array}{c}M_{n}{ }^{\mathrm{b}} \\
\times 10^{-3}\end{array}$ & $M_{w}{ }^{\prime} M_{n}{ }^{\mathrm{b}}$ \\
\hline 1 & $3.0 / 33.9$ & 20 & 4.72 & 50 & 125 & 1.96 \\
2 & $6.0 / 67.8$ & 40 & 23.8 & 25 & 364 & 1.43 \\
\hline
\end{tabular}

${ }^{a}$ Thermogravimetric analysis analysis.

bSize exclusion chromatography measurement.

Table 2 Melt-blending conditions for the preparation of polystyrene (PS)/PS-grafted-magadiite ${ }^{a}$

\begin{tabular}{lcc}
\hline Entry & Cylinder temperature (K) & Screw rotation (r.p.m.) \\
\hline 3 & 423 & 50 \\
4 & 423 & 100 \\
5 & 473 & 50 \\
6 & 473 & 100
\end{tabular}

akneading time of $5 \mathrm{~min} .0 .1 \mathrm{wt} \%$ of magadiite content.

cylinder temperatures, screw rotations and kneading times. PS- $g$ magadiite with $10 \mathrm{wt} \%$ of magadiite content was used as a masterbatch to dilute with excess amounts of PS to result in PS/PS- $g$ magadiite nanocomposites containing $0.1 \mathrm{wt} \%$ of magadiite under the four different melt-blending conditions shown in Table 2. Cylinder temperatures and screw rotations were selected as critical parameters to control the dispersion state of magadiite in PS matrices. Entry 3 shows a lower cylinder temperature and screw rotation. Entry 4 exhibits a lower cylinder temperature and higher screw rotation. Entry 5 shows a higher cylinder temperature and lower screw rotation. Entry 6 shows a higher cylinder temperature and screw rotation.

Figure 4 indicates optical microscopy images of four PS/PS- $g$ magadiite composites prepared under melt-blending conditions. Figure 4 (1) to (4) corresponds to Entries 3-6 in Table 2, respectively. Large agglomerates were observed in the composites seen in Figure 4 (1) and (3) (Entries 3 and 5). The agglomerates are PS- $g$-magadiite, and the other transparent parts are PS, which means that the phase separation of PS- $g$-magadiite and PS takes place at a macro scale. In contrast, no agglomerates were observed in the composites seen in Figure 4 (2) and (4) (Entries 4 and 6). As a result, PS-g-magadiite should be miscible with PS at less than a micron scale. These four PS/ PS- $g$-magadiite composites started from the same materials but were prepared under different melt-blending conditions; the differences in morphology are therefore due to the melt-blending conditions.

A lower screw rotation of 50 r.p.m. is common to the melt-blending conditions for preparing aggregated structures, as shown in Figure 4 (1) and (3) (Entries 3 and 5). In contrast, a higher screw rotation of $100 \mathrm{rpm}$ is common to the melt-blending conditions for preparing delaminated structures, as shown in Figure 4 (2) and (4) (Entries 4 and 6). These results suggest that screw rotation has a significant influence on the dispersion of PS-g-magadiite into PS among the melt-blending parameters. They also demonstrate that applying a strong mechanical force above a certain level to a mixture of PS and PS- $g$-magadiite at the melt states makes it possible to disentangle the aggregations of PS- $g$-magadiite to better disperse PS- $g$-magadiite into PS.

Flow properties of PS- $g$-magadiite and PS/PS- $g$-magadiite nanocomposites containing a $10 \%$ mass fraction of silicate were quantified by measuring their MFR. PS homopolymers had an MFR of

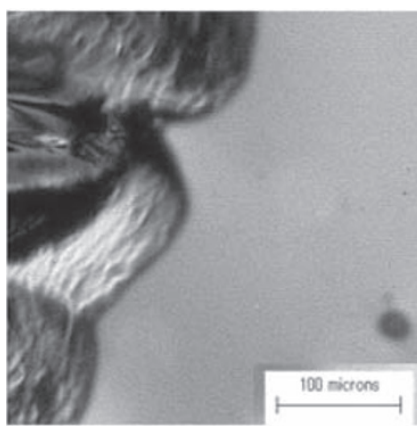

(1) Entry 3

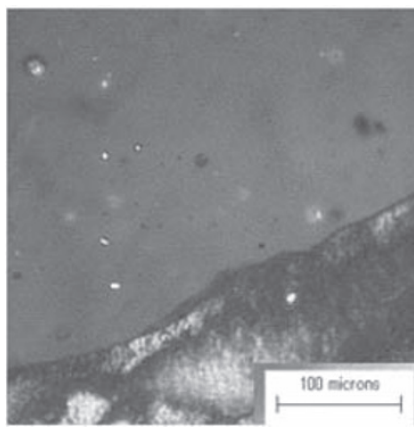

(3) Entry 5

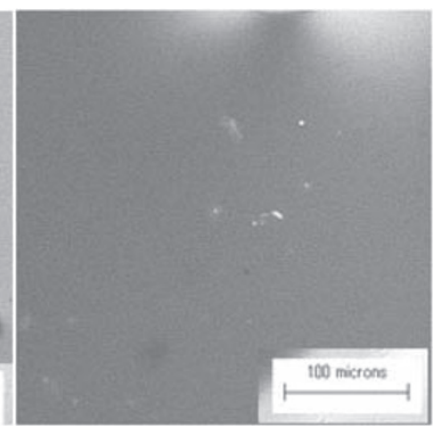

(2) Entry 4

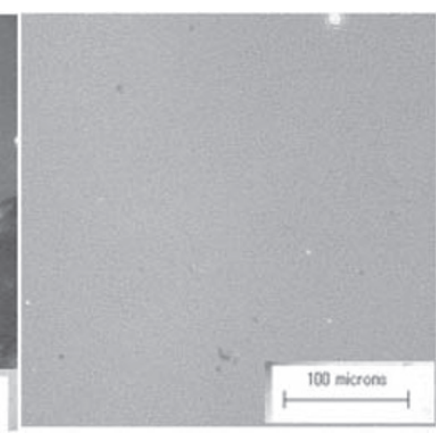

(4) Entry 6
Figure 4 Optical microscopy images of PS/PS-g-magadiite nanocomposites containing 0.1 wt \% of magadiite, and consisting of PS and PS-g-magadiite containing $10 \mathrm{wt} \%$ of magadiite, prepared under four melt-blending conditions with a Labo Plastomill $\mu$ equipped with a mixer at a kneading time of $5 \mathrm{~min}$. All samples (1) to (4) correspond to entries 3 to 6 in Table 2, respectively. The inserted scale bars are $100 \mu \mathrm{m}$.

$13 \mathrm{~g} / 10 \mathrm{~min}$. The MFR of PS- $\mathrm{g}$-magadiite nanocomposites could not be measured because of the absolute lack of fluidity. In contrast, PS/ PS- $g$-magadiite nanocomposites exhibited an MFR of $0.2 \mathrm{~g} / 10 \mathrm{~min}$. This indicates that test pieces can be made only from PS/PS- $g$ magadiite, and not from PS- $g$-magadiite nanocomposites.

\section{Dispersion states of magadiite at nanoscales in a series of polymer composites}

The sample compositions of a series of polymer composites are summarized in Table 3. All polymer magadiite composites contain a $10 \%$ mass fraction of silicate. Figures 5 and 6 exhibit XRD profiles and TEM images of a series of PS and PPE-PS composites, respectively. Figures 5 and 6 (4) and (8) show XRD profiles and TEM images of PS/ PS- $g$-magadiite and PPE/PS- $g$-magadiite nanocomposites prepared by the combination of surface-initiated polymerization and melt blending. The figures explain a delamination of magadiite in PS matrices and PPE-PS alloys, respectively. In contrast, Figures 5 and 6 (2) and (6) show XRD profiles and TEM images of PS/Na-magadiite and PPE$\mathrm{PS} / \mathrm{Na}$-magadiite composites prepared only by the melt-blending process. A sharp diffraction peak corresponding to the basal spacing of Na-magadiite was observed at $1.57 \mathrm{~nm}$, as seen in the XRD profiles of PS/Na-magadiite composites. In contrast, no sharp diffraction peaks for the layer structures of Na-magadiite were observed in the range of $2 \theta$ from 2 to 6 degrees, as seen in the XRD profile of PPE-PS/ Na-magadiite composites. This is presumably due to the disturbance in the regularity of the laminated structures of Na-magadiite by the mechanical force of melt blending at higher temperatures. However, 
Table 3 Sample compositions and flame-retardant properties of a series of polymer/magadiite composites ${ }^{\mathrm{a}}$

\begin{tabular}{|c|c|c|c|c|c|c|c|c|c|}
\hline \multirow[b]{2}{*}{ Abbreviations } & \multicolumn{5}{|c|}{ Component (wt\%) } & \multirow{2}{*}{$\begin{array}{c}\text { Magadiite } \\
\text { content (wt\%) }\end{array}$} & \multirow{2}{*}{$\begin{array}{c}\text { PHRR } \\
\left(\mathrm{kW} / \mathrm{m}^{-2}\right)\end{array}$} & \multirow{2}{*}{$\begin{array}{l}\text { Ignition } \\
\text { Time (s) }\end{array}$} & \multirow{2}{*}{$\begin{array}{c}\text { Residue } \\
\text { (wt\%) }\end{array}$} \\
\hline & $P S$ & $P P E$ & Na-magadiite & DTMA-magadiite ${ }^{\mathrm{b}}$ & PS-g-magadiite ${ }^{c}$ & & & & \\
\hline PS & 100 & 0 & 0 & 0 & 0 & 0 & 1086 & 33 & 1.7 \\
\hline PS/Na-magadiite & 90 & 0 & 10 & 0 & 0 & 10 & 933 & 18 & 9.1 \\
\hline PS/DT-magadiite & 86 & 0 & 0 & 14 & 0 & 10 & 572 & 21 & 10.1 \\
\hline PS/PS-g-magadiite & $60^{d}$ & 0 & 0 & 0 & $40^{d}$ & 10 & 517 & 30 & 9.4 \\
\hline PPE-PS & 35 & 65 & 0 & 0 & 0 & 0 & 500 & 28 & 19.8 \\
\hline PPE-PS/Na-magadiite & 31.5 & 58.5 & 10 & 0 & 0 & 10 & 417 & 23 & 21.6 \\
\hline PPE-PS/DT-magadiite & 30.1 & 55.9 & 0 & 14 & 0 & 10 & 412 & 22 & 21.4 \\
\hline PPE/PS-g-magadiite & $\mathrm{O}^{\mathrm{e}}$ & 58.5 & 0 & 0 & $41.5^{\mathrm{e}}$ & 10.4 & 429 & 38 & 28.1 \\
\hline
\end{tabular}

Abbreviations: DTMA, $n$-Dodecyltrimethylammonium chloride; PHRR, peak heat release rate; PPE, polyphenylene ether; PS, polystyrene; PS-g-magadiite, polystyrene-grafted magadiite. ${ }^{a}$ Cone calorimetric measurements at a heat flux of $50 \mathrm{~kW} \mathrm{~m}^{-2}$.

bDTMA-magadiite has $75.5 \mathrm{wt} \%$ of magadiite content.

CPS-g-magadiite containing $25 \mathrm{wt} \%$ of magadiite. All polymer magadiite composites contain a $10 \%$ mass fraction of silicate.

cPS-g-magadiite containing 25 wt $\%$ of magadiite. All polymer magad
dPS consists of pure PS and the bound PS from PS-g-magadiite.

${ }^{\mathrm{e}}$ All PS components are composed of the bound PS from PS-g-magadiite, without pure PS.
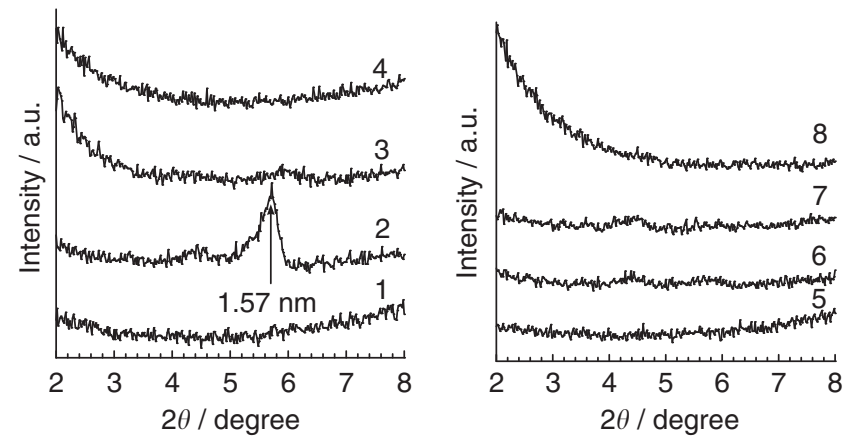

Figure 5 XRD patterns of a series of polymer/magadiite composites prepared through melt blending and compression molding. (1) PS, (2) PS/Namagadiite, (3) PS/DTMA-magadiite, (4) PS/PS-g-magadiite, (5) PPE-PS, (6) PPS-PS/Na-magadiite, (7) PPE-PS/DTMA-magadiite and (8) PPE/PS-gmagadiite. All polymer magadiite composites contain a $10 \%$ mass fraction of silicate. See Table 3.

only aggregations of Na-magadiite were observed as dark parts in TEM images. In addition, Figures 5 and 6 (3) and (7) exhibit XRD profiles and TEM images of PS/DTMA-magadiite and PPE-PS/ DTMA-magadiite composites prepared only by the melt-blending process. In fact, only agglomerated structures of DTMA-magadiite are present in PS matrices and PPE-PS alloys.

These results demonstrate that a combination of surface-initiated polymerization and melt blending is an effective approach to simultaneously improve the dispersibility of magadiite and the flow properties of nanocomposites. In addition, we can conclude that this approach has a beneficial effect not only on PS but also on PPE-PS alloys.

\section{The relative order in the dispersion state of magadiite in polymer} matrices

Figure 7 (1) to (4) exhibits the temperature dependencies of $\tan \delta$ in a series of PS composite sheets for which compositions are summarized in Table 3. All polymer magadiite composites contain a $10 \%$ mass fraction of silicate. The peaks observed around $382 \mathrm{~K}$ are assigned to the $\alpha$-absorption of PS. When a series of PS composites are arranged in the order of decreasing peak intensities of $\alpha$-absorption, they line up as follows: (1) PS > (2) aggregated PS/Na-magadiite composites
$>$ (3) aggregated PS/DTMA-magadiite > (4) exfoliated PS/PS- $g$ magadiite nanocomposites. This result suggests that the peak intensities of $\alpha$-absorption depend on the dispersion states of magadiite in PS matrices, thus decreasing with improvements in the dispersibility of magadiite in PS matrices. In other words, the reduction in the peak intensities of $\alpha$-absorption is due to the restraint on micro Brownian motion in PS main chains that resulted from the enhancement of interaction between the magadiite surface and PS chains, with an increase in interfacial areas between magadiite and the PS matrices being caused by an improvement in the dispersibility of magadiite in PS matrices.

Figure 7 (5) exhibits the temperature dependencies of PPE-PS. For the polymer blends system, no peaks around 382 and $483 \mathrm{~K}$ assignable to the $\alpha$-absorption of PS and PPE were observed. ${ }^{27}$ Only one peak for $\alpha$-absorption around $453 \mathrm{~K}$ was observed. This result means that PPE is miscible with PS, without phase separation. When a series of PPEPS composites are arranged in the order of decreasing peak intensities of $\alpha$-absorption, they line up as follows: (5) PPE-PS $>(6)$ aggregated PPE-PS/Na-magadiite composites $>(7)$ aggregated PPE-PS/DTMAmagadiite $>(8)$ exfoliated PPE/PS- $g$-magadiite nanocomposites. In particular, when magadiite was exfoliated into PPE-PS matrices, the intensities of $\alpha$-absorption were significantly decreased by the enhancement in the interfacial areas between magadiite platelets and polymer matrices. In addition, the peak of $\alpha$-absorption shifted to higher temperatures, as seen in Figure 7 (8). This shift suggests that PPE/PS- $g$-magadiite nanocomposites could exhibit thermal mechanical properties superior to those of any other PPE-PS/magadiite composites.

The relative order in the dispersibility of magadiite in various polymer matrices determined by the peak intensities of $\alpha$-absorption was consistent with the results of XRD and TEM.

\section{Thermal degradation behaviors}

Figure 8 (1) to (4) shows TGA curves of a series of PS composites for which the compositions are listed in Table 3. The TG curves shifted toward higher temperatures with an improvement in the dispersibility of magadiite in PS matrices. TG curves of a series of PPE-PS composites also shifted to higher temperatures with better dispersion of magadiite in PPE-PS matrices as shown in Figure 8 (5) to (8), except for PPE/PS-Na-magadiite. The thermal stability of PPE/PS-Namagadiite was inferior to that of PPE/PS alloy (6). Presumably, the 


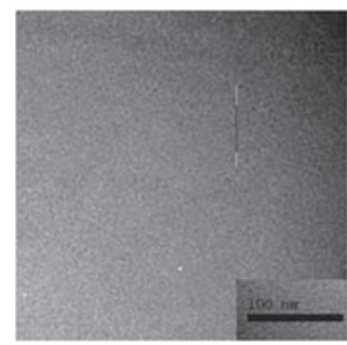

(1)

PS

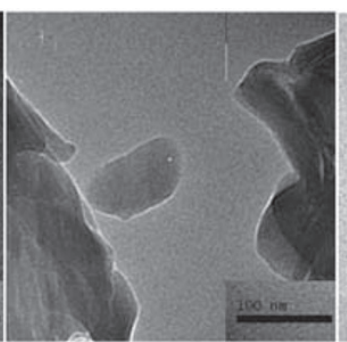

(2)

$\mathrm{PS} / \mathrm{Na}$-magadiite composites

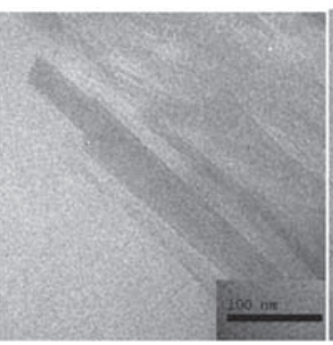

(3)

PS/DTMAmagadiite composites

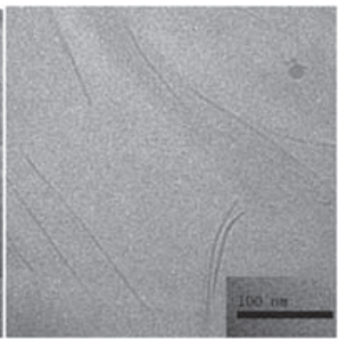

(4)

PS/PS-g-magadiite nanocomposites

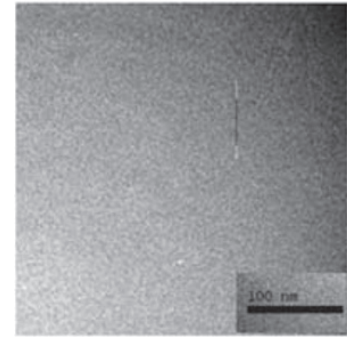

(5)

(65/35)

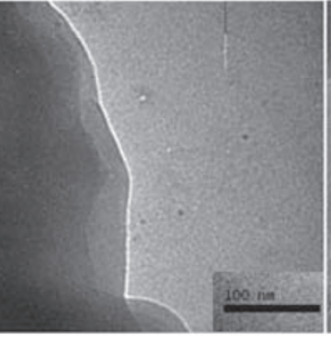

(6)

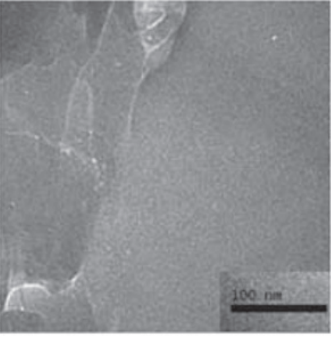

(7)

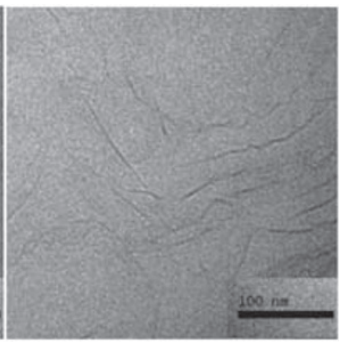

(8)

PPE-PS/DTMAmagadiite composites

PPE/PS- $g$-magadiite nanocomposites

Figure 6 TEM images of a series of polymer/magadiite composites prepared through melt blending and compression molding. All films measured $50 \mathrm{~nm}$ in thickness and were observed at blight field and a magnification of 200000 . The inserted scale bars are $100 \mathrm{~nm}$. (1) PS, (2) PS/Na-magadiite, (3) PS/DTMAmagadiite, (4) PS/PS-g-magadiite, (5) PPE-PS, (6) PPS-PS/Na-magadiite, (7) PPE-PS/DTMA-magadiite and (8) PPE/PS-g-magadiite. All polymer magadiite composites contain a $10 \%$ mass fraction of silicate. See Table 3.
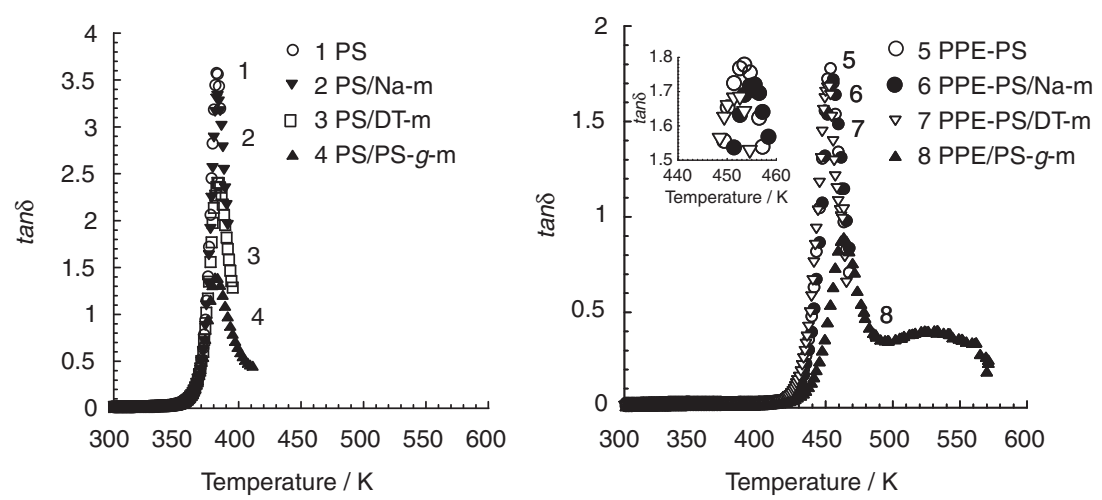

Figure 7 Temperature dependencies of $\tan \delta$ plots of a series of polymer/magadiite composite films at $11 \mathrm{~Hz}$. (1) PS, (2) PS/Na-magadiite, (3) PS/DTMAmagadiite, (4) PS/PS-g-magadiite, (5) PPE-PS, (6) PPS-PS/Na-magadiite, (7) PPE-PS/DTMA-magadiite and (8) PPE/PS-g-magadiite. The inserted figure is an enlarged detail within the range of $440-460 \mathrm{~K}$. All polymer magadiite composites contain a $10 \%$ mass fraction of silicate. See Table 3.

hydrolysis of PPE was caused by the basicity of Na-magadiite under higher temperatures. There is a definite relationship between the thermal stability of polymer matrices and the dispersion states of magadiite, except for PPE/PS-Na-magadiite. The pyrolysis of polymer matrices was essentially retarded with an improvement in dispersion states of magadiite in polymer matrices.

\section{Flammability properties of various dispersion states of magadiite in polymer matrices}

Table 3 summarizes the flammability properties of a series of polymer composite sheets evaluated by cone calorimetric measurements. All polymer magadiite composites contain a $10 \%$ mass fraction of silicate.
Figure 9 (1) to (4) exhibits the time-course plots for the HRR in a series of PS composites. The flammability properties of PS homopolymer are shown in Figure 9 (1). The PS homopolymer that burned out within a very short time exhibited the highest peak heat release rate (PHRR) in a series of PS composites. Figure 10 (1) shows photo images of PS homopolymer before and after the fire test. PS was almost completely decomposed during the fire test, and little residue remained. Figure 9 (2) illustrates the flammability properties of aggregated PS/Na-magadiite composites. PS/Na-magadiite composites exhibited the second highest PHRR. As shown in Table 3, the weight of the final residue of the PS/Na-magadiite composites was $9.1 \mathrm{wt} \%$ after the fire test, the value was almost equal to the initial 

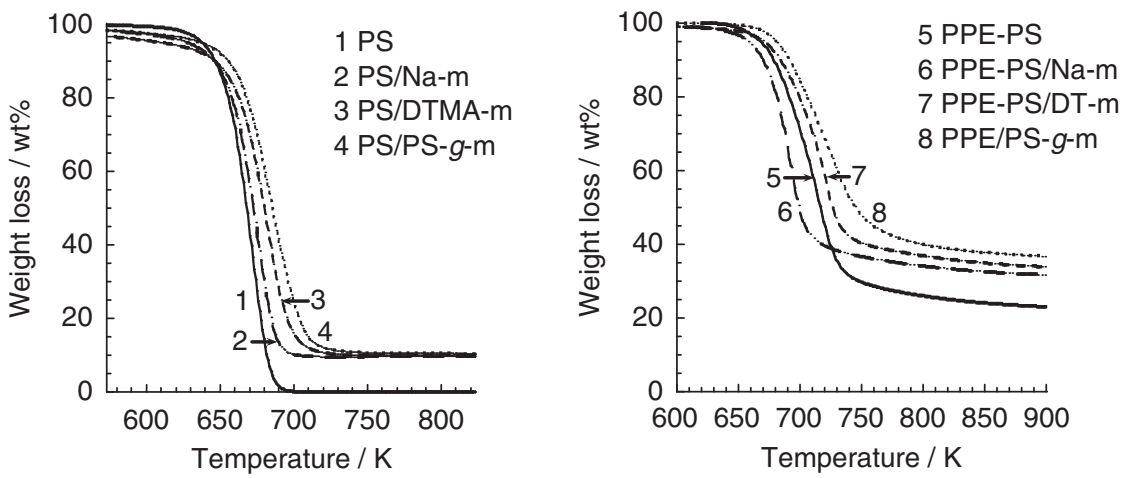

Figure 8 TG curves of a series of polymer/magadiite composites. (1) PS, solid line; (2) PS/Na-magadiite, long broken line; (3) PS/DTMA-magadiite, short broken line; (4) PS/PS-g-magadiite, dotted line; (5) PPE-PS, solid line; (6) PPS-PS/Na-magadiite, long broken line; (7) PPE-PS/DTMA-magadiite, short broken line; and (8) PPE/PS-g-magadiite, dotted line. All polymer magadiite composites contain a 10\% mass fraction of silicate. TGA was conducted in a nitrogen stream of $200 \mathrm{ml} \mathrm{min}^{-1}$ at a heating rate of $10 \mathrm{~K} \mathrm{~min}^{-1}$ from 303 to $1173 \mathrm{~K}$. See Table 3.
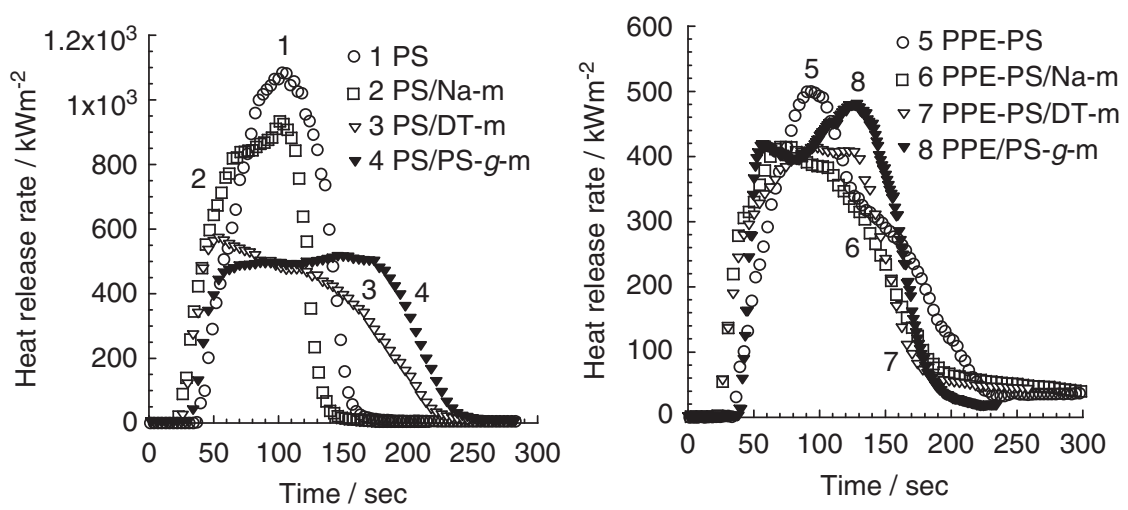

Figure 9 Time-course plots for HRR of a series of polymer/magadiite composite plates $\left(100 \times 100 \times 3 \mathrm{~mm}^{3}\right)$ by cone calorimetric measurements at a heat flux of $50 \mathrm{~kW} \mathrm{~m}^{-2}$. (1) PS, (2) PS/Na-magadiite, (3) PS/DTMA-magadiite, (4) PS/PS-g-magadiite, (5) PPE-PS, (6) PPS-PS/Na-magadiite, (7) PPE-PS/DTMAmagadiite and (8) PPE/PS-g-magadiite. All polymer magadiite composites contain a 10\% mass fraction of silicate. See Table 3.

Na-magadiite content in the PS matrix. Thus, the residue shown in Figure 10 (2) consists almost entirely of powdery silicates. Aggregated Na-magadiite did not improve the flame-retardant properties of PS. As Figure 9 (3) shows the flammability properties of aggregated PS/ DTMA-magadiite composites, their PHRR values were $53 \%$ of that of PS, which allowed them to keep burning for a relatively long time, with suppression of thermal decomposition of PS. The aggregated PS/ DTMA-magadiite composites showed better flame-retardant properties due to the improvement in magadiite dispersibility, compared with PS/Na-magadiite composites, but the residue remained as only powdery silicates. Figure 9 (4) displays the flammability properties of exfoliated PS/PS- $g$-magadiite nanocomposites that exhibited the smallest PHRR value, which was $48 \%$ of that of PS, with suppression of the thermal decomposition of PS to keep burning for the longest time among the series of PS composites. The residue remained as only silicates but the appearance was unique. Interestingly, the silicate residues formed strong and seamless solids, without powdery silicates, as shown in Figure 10 (4). The silicate solids were tough enough to handle. The strong and seamless solid formation can be expected to contribute to improvements in flammability in the vertical flame test and to provide an advantage in preventing the fire spread caused by the breakup of polymer composite materials in an actual fire disaster.

Figure 9 (5) to (8) exhibits the time-course plots for HRR in a series of PPE-PS composites. There were no remarkable changes in PHRR

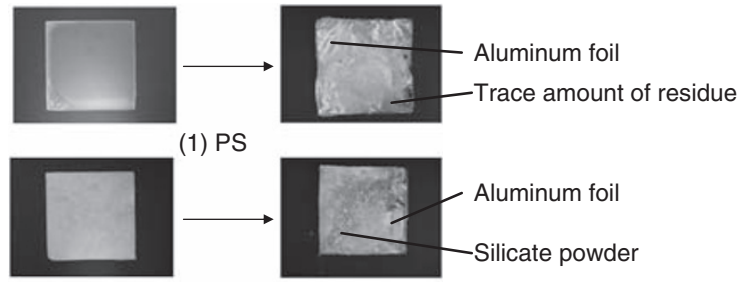

(2) PS/Na-m

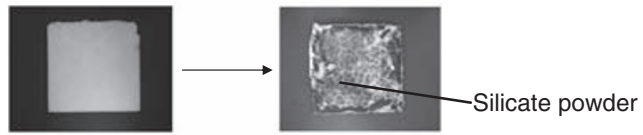

(3) PS/DT-m

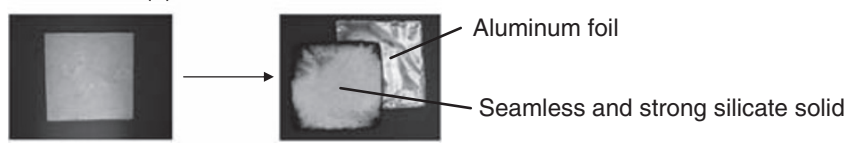

(4) PS/PS- $g-m$

Figure 10 Photo images of a series of PS/magadiite composite plates $\left(100 \times 100 \times 3 \mathrm{~mm}^{3}\right)$ on aluminum foil before and after the flame-retardant test by cone calorimetric measurements at a heat flux of $50 \mathrm{~kW} \mathrm{~m}^{-2}$. (1) PS, (2) PS/Na-magadiite, (3) PS/DTMA-magadiite and (4) PS/PS-g-magadiite. All polymer magadiite composites contain a $10 \%$ mass fraction of silicate. See Table 3. 
even with the improvement in the dispersibility of magadiite in PPEPS alloys. This behavior is presumably due to a mismatch between the properties that led to the formation of 'intumescent layers' inherent to PPE during burning and the maintenance of the sample shape caused by delaminated magadiite. Intumescent layers are expansion layers in which diffusion of decomposed products and heat transfer are suppressed. Intumescent layers are formed on the surface during combustion, as in bread expanding with baking powder. ${ }^{28-31}$ Significant expansion of the residue was observed in the lateral image of PPE-PS residues after burning, as shown in Figure 11 (1). The PHRR of PPE-PS was found to be less than half of that of PS, as seen in Figure 9 (1) and (5). One of the factors related to the flame-retardant performances of PPE-PS likely involves the contribution of the formation of intumescent layers to the suppression of diffusion in decomposed products and heat transfer. It is known that intumescent layers become thicker, and that higher temperatures from the fire source are required to maintain combustion. When the thickness of formed intumescent layers reaches $0.01,0.1$ and $1.0 \mathrm{~cm}$, the external temperatures for maintaining combustion should correspond to approximately 615,1000 and $4860 \mathrm{~K}$, respectively. ${ }^{32}$ However, PPEPS showed a relatively high PHRR of $500 \mathrm{kWm}^{-2}$, even though the thickness of their formed intumescent layers reached more than several centimeters. This result is presumably due to the imperfection of the formed intumescent layers. Moreover, intumescent layers were formed in aggregated PPE-PS/Na-magadiite composites and PPE-PS/ DTMA-magadiite composites, and the collapsed parts of the intumescent layers were observed from their top views, as seen in Figure 11 (2) and (3). These intumescent layers contribute somewhat to the flame-retardant properties, but the PHRR value of approximately
$410 \mathrm{kWm}^{-2}$ remains relatively high because of their imperfect and fragile insulating layers, as seen in Figure 9 (6) and (7). The most interesting result is the burning behavior of exfoliated PPE/PS-gmagadiite nanocomposites, as seen in Figure 11 (4). The intumescence formation of PPE was perfectly suppressed during combustion, resulting in curved solid residues instead. With this lack of intumescence formation, there should be a corresponding increase in PHRR with a deterioration in the flame-retardant properties. However, any notable changes in PHRR values were not observed as compared with (5) PPE-PS and (8) PPE/PS-g-magadiite in Figure 9. This result is due to the substitution of the incombustible and strong solid formation composed of a large number of exfoliated magadiite platelets for the intumescence formation, resulting in almost no apparent changes in their PHRR.

These results demonstrated that there is a close relationship between the dispersibility of magadiite and the flame-retardant properties of PS/magadiite composites; their PHRR decreased with improvements in the dispersibility of magadiite in PS matrices. In particular, when magadiite was exfoliated into PS matrices at nanoscales, PS/PS- $g$ magadiite nanocomposites were found to exhibit the least PHRR during burning, as well as to form strong and seamless solids composed of incombustible silicates. In contrast, there was no definite correlation between the dispersibility of magadiite and the flameretardant properties of PPE-PS/magadiite composites.

\section{CONCLUSION}

Polystyrene/magadiite and PPE-PS/magadiite nanocomposites, with both processibility and exfoliated dispersion of magadiite, were successfully prepared by a combination of surface-initiated radical

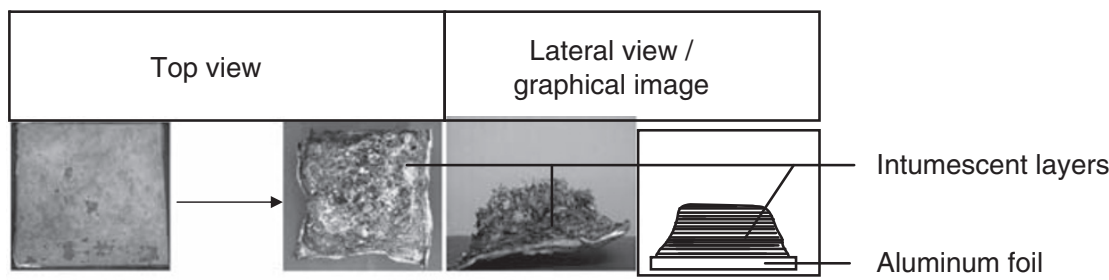

(1) PPE-PS

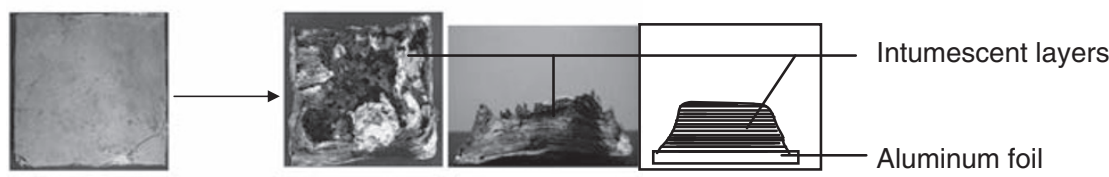

(2) PPE-PS/Na-m

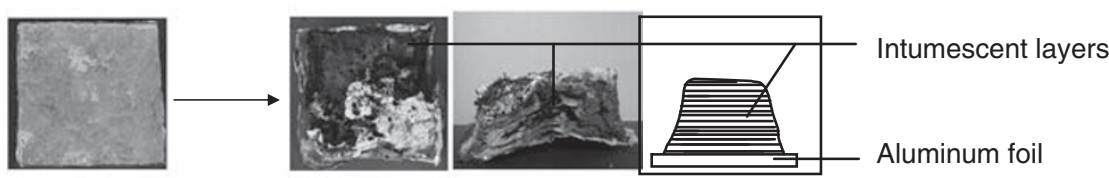

(3) PPE-PS/DT-m

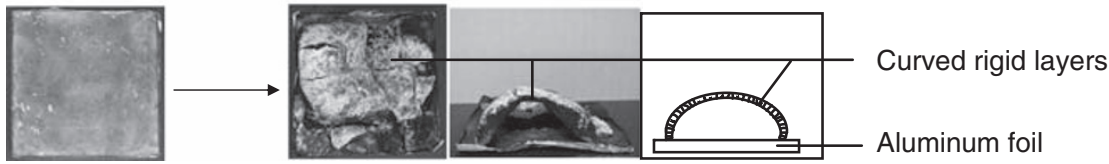

(4) PPE/PS- $g-m$

Figure 11 Photo and graphical images of a series of PPE-PS/magadiite composites plates $\left(100 \times 100 \times 3 \mathrm{~mm}^{3}\right)$ on aluminum foil before and after the flame-retardant test by cone calorimetric measurements at a heat flux of $50 \mathrm{~kW} \mathrm{~m}^{-2}$. (1) PPE-PS, (2) PPS-PS/Na-magadiite, (3) PPE-PS/DTMA-magadiite and (4) PPE/PS-g-magadiite. All polymer magadiite composites contain a 10\% mass fraction of silicate. See Table 3. 
polymerization and a melt blending process. PS- $g$-magadiite was delaminated into PS and PPE homopolymers by applying a specific mechanical force to each mixture at melt states. For a series of PS/ magadiite composites, PHRR values decreased with improvements in the dispersibility of magadiite. In particular, exfoliated PS/magadiite nanocomposites exhibited the lowest PHRR values to keep burning the longest time among a series of PS composites. Therefore, the dispersibility of magadiite in PS matrix was found to be the most important factor for improvement in the flame-retardant properties of PS/magadiite composites. It was also revealed that magadiite becomes a desirable material with high flame-retardant performances due to the formation of seamless and strong solid residue only if magadiite can be successfully delaminated into PS matrices. In contrast, a series of PPE-PS/magadiite composites showed no definite correlation between the improvement in the dispersibility of magadiite and the suppression of PHRR. This is due to interference in the intumescence formation of PPE by maintenance effects of shape caused by a large number of delaminated magadiite platelets. Consequently, exfoliated magadiite can be effective for improving the incombustible properties of PS, but not PPE-PS alloy.

\section{ACKNOWLEDGEMENTS}

We thank Mr Yuyu Ohnuma, Mr Akio Hashizume, Dr Kenichirou Hiwatari, Mr Tetsuo Kamimoto, Dr Mitsuru Fukushima, Mr Toshinori Yukino, Dr Hisashi Murase and Dr Ryoji Kimura in ADEKA Corporation for supporting.

1 Gilman, J. W. Flammability and thermal stability studies of polymer layered-silicate (clay) nanocomposites. Appl. Clay Sci. 15, 31-49 (1999).

2 Morgan, A. B., Harris, R. H. Jr., Kashiwagi, T., Chyall, L. J. \& Gilman, J. W. Flammability of polystyrene layered silicate (clay) nanocomposites: carbonaceous char formation. Fire Mater. 26, 247-253 (2002).

3 Laachachi, A., Leroy, E., Cochez, M., Ferriol, M. \& Lopez Cuesta, J. M. Use of oxide nanoparticles and organoclays to improve thermal stability and fire retardancy of poly(methyl methacrylate). Polym. Deg. Stab. 89, 344-352 (2005).

4 Kashiwagi, T., Morgan, A. B., Antonucci, J. M., Vanlandingham, M. R., Harris, R. H. Jr., Awad, W.H. \& Shields, J. R. Thermal and flammability properties of a silica-poly(methyl methacrylate) nanocomposite. J. Appl. Polym. Sci. 89, 2072-2078 (2003).

5 Kashiwagi, T., Grulke, E., Hilding, J., Groth, K., Harris, R., Butler, K., Shields, J., Kharchenko, S. \& Douglas, J. Thermal and flammability properties of polypropylene/ carbon nanotube nanocomposites. Polymer. 45, 4227-4239 (2004).

6 Kashiwagi, T., Du, F., Douglas, J. F., Winey, K. I., Harris, R. H. Jr. \& Shields, J. R. Nanoparticles networks reduce the flammability of polymer nanocomposites. Nat. Mater. 4, 928-933 (2005).

7 Kashiwagi, T., Du, F., Winey, K. I., Groth, K. M., Shields, J. R., Bellayer, S. P., Kim, H. \& Douglas, J. F. Flammability properties of polymer nanocomposites with single-walled carbon nanotubes: effects of nanotube dispersion and concentration. Polymer. 46, 471-481 (2005).

8 Dasari, A., Yu, Z.- Z., Mai, Y.- W., Cai, G. \& Song, H. Roles of graphite oxide, clay and POSS during the combustion of polyamide 6. Polymer. 50, 1577-1587 (2009).

9 Glodek, T.E., Boyd, S. E., Mcaninch, I. M. \& Lascala, J. J. Properties and performance of fire resistant eco-composites using polyhedral oligomeric silsesquioxane (POSS) fire retardants. Comp. Sci. Technol. 68, 2994-3001 (2008).
10 Morgan, A. B., Chu, L.- L. \& Harris, J. D. A flammability performance comparison between synthetic and natural clays in polystyrene nanocomposites. Fire Mater. 29, 213-229 (2005).

11 Kashiwagi, T., Mu, M., Winey, K., Cipriano, B., Raghavan, S. R., Pack, S., Rafailovich, M., Yang, Y., Grulke, E., Shields, J., Harris, R. \& Douglas, J. Relation between the viscoelastic and flammability properties of polymer nanocomposites. Polymer. 49, 4358-4368 (2008).

12 Kong, Q., Hu, Y., Song, L. \& Yi, C. Synergistic flammability and thermal stability of polypropyrene/aluminun trihydroxide/Fe-montmorillonite nanocomposites. Polym. Adv. Technol. 20, 404-409 (2009).

13 Gilman, J. W., Jackson, C. L., Morgan, A. B. \& Harris, R. Jr. Flammability properties of polymer-layered-silicate nanocomposites. polypropylene and polystyrene nanocomposites. Chem. Mater. 12, 1866-1873 (2000).

$14 \mathrm{Hu}$, Y., Wang, S., Ling, Z., Zhuang, Y., Chen, Z. \& Fan, W. Preparation and combustion properties of flame retardant nylon 6/montmorillonite nanocomposites. Macromol. Mater. Eng. 288, 272-276 (2003).

15 Zanetti, M., Kashiwagi, T., Falqui, L. \& Camino, G. Cone calorimeter combustion and gasification studies of polymer layered silicate nanocomposites. Chem. Mater. 14, 881-887 (2002).

16 Bourbigot, S., Vanderhart, D. L., Gilman, J. W., Bellayer, S., Stretz, H. \& Paul, D. R. Solid state NMR characterization and flammability of styrene-acrylonitrile copolymer montmorillonite nanocomposites. Polymer. 45, 7627-7638 (2004).

17 Zhang, Y., Hu, Y., Song, L., Wu, J. \& Fang, S. Influence of Fe-MMT on the fire retarding behavior and mechanical property of (ethylene-vinyl acetate copolymer/magnesium hydroxide) composite. Polym. Adv. Technol. 19, 960-966 (2008).

18 Wang, D., Jiang, D. D., Pabst, J., Han, Z., Wang, J. \& Wilkie, C. A. Polystyrene magadiite nanocomposites. Polym. Eng. Sci. 44, 1122-1131 (2004).

19 Moniruzzaman, M. \& Winey, K. I. Polymer nanocomposites containing carbon nanotubes. Macromolecules. 39, 5194-5205 (2006).

20 Okutomo, S., Kuroda, K. \& Ogawa, M. Preparation and characterization of silylatedmagadiites. Appl. Clay Sci. 15, 253-264 (1999).

21 Kosuge, K. \& Tsunashima, A. Dispersion of $\mathrm{H}$-magadiite and $\mathrm{H}$-kenyaite particles by ion exchange of $\mathrm{H}^{+}$with alkali ions. Langmuir. 12, 1124-1126 (1996).

22 Yukutake, H., Kobayashi, M., Otsuka, H. \& Takahara, A. Thermal degradation behavior of polystyrene/magadiite nanocomposites prepared by surface-initiated nitroxidemediated radical polymerization. Polym. J. 41, 555-561 (2009).

23 Weeks, N. E., Karasz, F. E. \& Macknight, W. J. Enthalpy of mixing of poly(2,6-dimethyl phenylene oxide) and polystyrene. J. Appl. Phys. 48, 4068-4071 (1977).

24 Lovera, D., Ruckdäschel, H., Göldel, A., Behrendt, N., Frese, T., Sandler, J. W., Altstädt, V., Giesa, R. \& Schmidt, H.- W. Tailored polymer electrets based on poly(2,6-dimethyl-1,4-phenylene ether) and its blends with polystyrene. Eur. Polym. J. 43, 1195-1201 (2007).

25 Kosuge, K., Yamazaki, A., Tsunashima, A. \& Otsuka, R. Hydrothermal synthesis of magadiite and kenyaite. J. Ceram. Soc. Jpn. 100, 326-331 (1992).

26 Eypert-Blaison, C., Sauzéat, E., Pelletier, M., Michot, L. J., Villiéras, F. \& Humbert, B. Hydration Mechanisms and Swelling Behavior of Na-Magadiite. Chem. Mater. 13, 1480-1486 (2001).

27 Chin, Y. H., Zhang, C., Wang, P., Inglefield, P. T., Jones, A. A., Kambour, R. P., Bendler, J. T. \& White, D. M. Glass transition dynamics in a compatible blend by twodimensional solid-state NMR. Macromolecules. 25, 3031-3038 (1992).

28 Takeda, K. Non-Halogenation, Reduced Smoke Evolution and Countermeasures against Dioxin in Flame-Retardant Materials // 23-26 (Technical Information Institute, Tokyo, 1998).

29 Halpern, Y., Mott, D. M. \& Niswander, R. H. Fire retardancy of thermoplastic materials by intumescence. Ind. Eng. Chem. Prod. Res. Dev. 23, 233-238 (1984).

30 Vandesall, H. L. Intumescent coating systems, their development and chemistry. J. Fire Flammability. 2, 97-140 (1971).

31 Marchal, A., Delobel, R., Bras, M. L., Leroy, J.- M. \& Price, D. Effect of intumescence on polymer degradation. Polym. Deg. Stab. 44, 263-272 (1994).

32 Funt, J. M. \& Magill, J. H. Estimation of the fire behavior of polymers. J. Fire Flammability. 6, 28-36 (1975) 